\title{
DYNAMICS AND MANAGEMENT OF THE INDIAN \\ MACKEREL RASTRELLIGER KANAGURTA (CUVIER, 1816) IN THE GULF OF SUEZ, EGYPT
}

\author{
Sahar F. Mehanna \\ National Institute of Oceanography and Fisheries \\ P. O. Box 182, Suez, Egypt
}

Key words: Rastrelliger kanaguria, Scombridae, Gulf of Suez, age and growth, mortality rates, yield per recruit

\section{ABSTRACT}

B ased on the otolith's readings of 678 specimens collected during the fishing season 1998/1999, age, growth, mortality and yield per recruit of Rastrelliger kanagurta from the Gulf of Suez were studied. Age composition showed no variation between the two sexes. The oldest males and females were four years old. The values of the von Bertalanffy growth parameters were $\mathrm{K}=0.66$ year $^{-1}$ and $\mathrm{L}_{\infty}=29.48$ $\mathrm{cm}$ for males and $\mathrm{K}=0.60$ year $^{-1}$ and $\mathrm{L}_{\infty}=32.04 \mathrm{~cm}$ for females. The mean total mortality coefficient " $\mathrm{Z}$ " was found to be 1.12 year $^{-1}$ for males and 1.00 year $^{-1}$ for females. The natural mortality coefficient "M" was 0.26 year $^{-1}$ for males and 0.25 year $^{-1}$ for females. The yield per recruit was estimated using the parameters obtained for the combined sexes. The results suggest that the present level of fishing mortality $(F=0.82)$ is much higher than that which gives the maximum yield per recruit.

\section{INTRODUCTION}

The Gulf of Suez is one of the most important fishing grounds in Egypt. It yields an average annual catch of 20,000 ton. The purseseine is the common gear for pelagic fishery in the Gulf with an average annual total catch of 15,536 ton (during the period from the fishing season 1985/1986 to 1998/1999). The purse-seine catch composed of a mixture of fish species of which the indian mackerel, Rastrelliger kanagurta is among the most important species.

Despite the commercial importance of the indian mackerel in the Gulf of Suez, there are very few studies concerning its biology and dynamies. Rafail (1972) studied age. growth and mortality rates of R. kuncultial from Red Sea near Al-Ghardaqa. Sanders et al. (1984) 
investigated age, growth and mortality rates of $R$. kanaguita from the Gulf of Suez.

On the other hand, many studies were carried out dealing with the biology and dynamics of $R$. kanagurta on other localities. Guanco (1991) investigated the growth and mortality of $R$. kanagurta in Philippines; Edwards and Shaher (1991) estimated the growth parameters of $R$. kanagurta from the Gulf of Aden; Torres (1991) estimated the growth parameters of $R$. kanagurta in Southern Africa.

For a judicious exploitation and management of this species, information on its biology and dynamics is essential. Thus, this study is undertaken to obtain the basic information required for the management of this valuable fish species in the Gulf of Suez.

\section{MATERIAL AND METHODS}

Monthly random samples of $R$. kanagurta were collected from the local market of Suez City during the period from September 1998 to April 1999. The total length to the nearest millimeter, total weight to the nearest $0.1 \mathrm{~g}$ and sex were recorded for each specimen.

Otoliths were used for age determination of $\mathrm{R}$. kanagurta. Otoliths were taken out, cleaned carefully and washed in distilled water, then examined using optical system consisting of Nikon ZoomStereomicroscope focusing block, Heidenhain's electronic bidirectional read out system VR X 182, under transmitted light. The total radius of the otolith and the radius of each annulus were measured to the nearest $0.001 \mathrm{~mm}$. The body total length-otolith radius relationship was determined by using the least square method. The lengths at previous ages were back- calculated from otolith measurements using Lee's equation (1920).

The power equation $(\mathrm{W}=\mathrm{aL})$ was applied to describe the relationship between the total length (L) and the total weight (W).

The growth parameters of the von Bertalanffy growth model ( $\mathrm{K}$ and $L_{\infty}$ ) were estimated using the method of Ford (1933)-Walford (1946).

Total mortality coefficient " $\mathrm{Z}$ " is estimated using the methods of Ricker (1975) which is based on the analysis of catch curve using age composition data and Jones and Van Zalinge (1981) which is based on the analysis of catch curve used length frequency data. 
age composition data and Jones and Van Zalinge (1981) which is based on the analysis of catch curve used length frequency data.

Natural mortality coefficient " $M$ " was estimated using the formula suggested by Ursin (1967), while the fishing mortality coefficient " $F$ " was computed as $F=Z-M$.

The yield per recruit of $R$. kanagurta was computed by applying the model of Beverton and Holt (1957).

\section{RESULTS AND DISCUSSION}

\section{Age Composition}

The age composition of $R$. kanagurta showed no variation between the two sexes (Table 1). The oldest males and females were four years old. The present data show that age group II is the dominant age group in the catch for both sexes and constituted $57.43 \%$ for males and $55.22 \%$ for females. This means that $R$. kanagurta in the Gulf of Suez becomes fully recruited to the purse-seine fishery at an age of two years.

\section{Growth in Length}

\section{A- Body Length - Orolith Radius Relationship}

Otolith's measurements of 343 males and 335 females were used for the estimation of the body length-otolith radius relationship of $R$. kanagurta collected from the Gulf of Suez. This relationship is linear and can be represented by the following equations:

$$
\text { For males } \mathrm{L}=3.45209+7.95719 \mathrm{~S} \quad(\mathrm{r}=0.9986)
$$

For females $\mathrm{L}=4.00060+7.77050 \mathrm{~S} \quad(\mathrm{r}=0.9895)$

where $\mathrm{L}=$ the total length in centimeter,

$\mathrm{S}=$ the otolith radius in millimeter

$\mathrm{r}=$ the correlation coefficient.

\section{B-Back - Calculations}

The back-calculated lengths at the end of different years of life of both sexes of R kanagurta were computed according to Lee's equation as follows:

For males $L_{n}=(L-3.45289) \mathrm{S}_{n} / \mathrm{S}+3.45289$

For females $\mathrm{L}_{\mathrm{n}}=(\mathrm{L}-4.00060) \mathrm{S}_{\mathrm{n}} / \mathrm{S}+4.00060$ 
where $L_{n}=$ the calculated length at the end of $n^{\text {th }}$ year,

$\mathrm{L}=$ the total length at capture,

$S_{n}=$ the otolith radius to $n^{\text {th }}$ annulus

$\mathrm{S}=$ the total otolith radius in millimeter.

The back-calculated lengths are given in Tables 2 and 3 . The results show that males reach $14.8,21.9,25.6$ and $27.4 \mathrm{~cm}$ at the end of $1^{\text {st }}, 2^{\text {nd }}, 3^{\text {rd }}$ and $4^{\text {th }}$ year of life respectively while females attain $15.6,22.9,27.3$ and $29.3 \mathrm{~cm}$ at the end of $1^{\text {st }}, 2^{\text {thd }}, 3^{\text {rd }}$ and $4^{\text {th }}$ year of life respectively. It is evident that both males and females attain their highest growth rate in length during the first year of life, after which, the annual increment in length decreases with further increase in age until it reaches its minimum value at the end of the $4^{\text {th }}$ year of life. This result is in a good agreement with the finding of George and Banerji (1964) who reported that the young stages of $R$. kanagurta are characterized by a higher growth rate than the old ones. Seshappa (1969) found that the indian mackerel reaches a total length of $11-15$ $\mathrm{cm}, 21-24 \mathrm{~cm}, 25-27 \mathrm{~cm}$ and $28-29 \mathrm{~cm}$ by the end of the $1^{\mathrm{st}}, 2^{\text {nd }}$, $3^{\text {rd }}$ and $4^{\text {th }}$ year of life, respectively. Rafail (1972) found that the $R$. kanagurta from Red Sea, Egypt attains lengths of 18.0, 24.0 and 28.5 $\mathrm{cm}$ by the end of the $1^{\text {st }}, 2^{\text {nd: }}$ and $3^{\text {rd }}$ year of life, respectively. Luther (1973) gave lengths of $14.8,21.8,26.5$ and $30.2 \mathrm{~cm}$ for the $1^{\text {st }}, 2^{\text {nd }}, 3^{\text {rd }}$ and $4^{\text {th }}$ year of life, respectively for $R$. kanagurta from Andaman Islands, India.

\section{Length - Weight Rejationship}

For the esiimation of the length - weight relationship of $R$. kanagurta in the Gulf of Suez, the measurements of 343 males and 335 females were used. The lengths of males ranged between 14.3 and $27.7 \mathrm{~cm}$ and their weights varied from 25 and $226 \mathrm{~g}$, while the lengths of females varied from 14.5 and $29.9 \mathrm{~cm}$ and their weights ranged between 26 and $282 \mathrm{~g}$. The calculated length-weight equations were found to be:

For males

$$
\begin{aligned}
& \mathrm{W}=0.00548 \mathrm{~L}^{3.19871} \quad(\mathrm{r}=0.9968) \\
& \mathrm{W}=0.00607 \mathrm{~L}^{3.16818} \\
& (r=0.9984)
\end{aligned}
$$

For females

The values of the power " $b$ " obtained from the present study are more or less similar to those mentioned from the previous studies. Luther (1973) gave a " $b$ " value of 3.2541 for males and 3.3149 for females of $R$. kanagurta from Andaman Islands. Sudjastani (197?: 
gave a "b" value of 3.19 for $R$. kanagurta from Java Sea. Anon (1985) mentioned a value of " $\mathrm{b}$ " equal to 3.22 for $R$. kanagurta from west coast Malaysia and 3.09 from Malaysia.

\section{Growth in Weight}

Tables 4 and 5 show the calculated weights at the end of each year of life for males and females of $R$. kanagurta, respectively. The results indicated that for both males and females, the growth in weight is very slow during the first year of life and the annual increment in weight increases with further increase in age until it reaches its maximum value at age group II for males and III for females after which a decreasing in the annual increment was noticed.

\section{Theoretical Growth}

In the present study, the growth model of von Bertalanffy was applied. The growth parameters of the von Bertalanffy growth model were computed by applying the method of Ford (1933)-Walford (1946) as follows:

$$
L_{t+1}=L_{\infty}\left(1-e^{-K}\right)+e^{-K} L_{t}
$$

where $L_{t}$ and $L_{t+1}$ are the length at age "t" and "t+1" respectively.

The growth parameters of $R$. kanagurta from the Gulf of Suez are shown in Table "6" along with those reported by other authors. The present study indicated that the asymptotic total length of the combined sexes of $R$. kanagurta from the Gulf of Suez was $32.15 \mathrm{~cm}$ while it was $42 \mathrm{~cm}$ at Red Sea (Rafail, 1972) and $40 \mathrm{~cm}$ at the Gulf of Suez (Sanders et al, 1984). On the other hand; the value of $K$ in the present study was 0.57 , while it was 0.29 (Rafail, 1972) and 0.23 (Sanders et al, 1984), indicating that the indian mackerel fish in the present study reach their asymptotic total length faster than those recorded in Rafail (1972) and Sanders et al. (1984) The present values of the growth parameters was found to be in the range of those recorded for the same species in other localities (Table 6). 


\section{Mortality}

\section{Total Mortality Coefficient " $\mathrm{Z}$ "}

In the present study, two different methods were applied to estimate the total mortality coefficient " $Z$ ". The first is based on the analysis of age composition data (semilogarithmic regression method of Ricker, 1975) and the second is based on the analysis of length composition data (cumulated catch curve method of Jones and Van Zalinge, 1981).

The present results (Table 7 and Figs. $1 \& 2$ ) indicate that the estimated values of " $Z$ " from the two different methods are very close to each other.

\section{Natural Mortality Coefficient "M"}

In the present study, the formula suggested by Ursin (1967) was applied to estimate the natural mortality coefficient " $M$ ". This formula can be expressed as $M=W^{-1 / 3}$. The values of " $M$ " were 0.2611 for males and $0.25: 14$ for females.

\section{Fishing Mortality Coefficient "F"}

Fishing mortality coefficient " $F$ " was estimated as $\mathrm{F}=\mathrm{Z}-\mathrm{M}$. It is found that $F=\mathbf{0 . 8 6}$ for males and 0.7536 , for females.

\section{Yield per Recruit "Y/R"}

The model of Beverton and Holt (1957), which was based on the estimation of the yield per recruit under a particular set of fishing mortality coefficients, was applied. The input parameters used in Beverton and Holt model are the growth and mortality parameters of the combined sexes. These parameters are as follows:

$$
\begin{array}{lll}
\mathrm{L}_{\infty}=32.15 \mathrm{~cm} & \mathrm{~W}_{\infty}=362.41 \mathrm{~g} & \mathrm{~K}=0.5734 \text { year }^{-1} \\
\mathrm{M}=0.2560 \text { year }^{-1} & \mathrm{~F}=\text { variable } & \mathrm{T}_{\mathrm{r}}=0.8507 \text { year }^{-1} \\
\mathrm{~T}_{\mathrm{c}}=\text { variable } & \mathrm{t}_{\mathrm{o}}=-0.0529 \text { year } & \mathrm{Z}=1.0786 \text { year }^{-1}
\end{array}
$$

The estimated yield per recruit of $R$. kanagurta in the Gulf of Suez is represented graphically in Fig. 3. The results indicate that, the yield per recruit was zero when the fishing mortality was zero, then the yield per recruit increases rapidly as the fishing mortality increases and reaches its maximum value at fishing mortality coefficient of 0.4 after which the yield per recruit decreases with further increase of 
Dynamics and management of the indian mackerel 185 Rastrelliger kanagurta (Cuvier, 1816) in the gulf of Suez, Egypt

fishing mortality (Fig. 3). The results indicate also that, at the present level of fishing mortality coefficient $(F=0.8226)$, age at first capture $\left(T_{c}=0.97\right.$ year $)$ and natural mortality coefficient $(M=0.256)$, the yield per recruit was estimated to be $78.99 \mathrm{~g}$. This means that, the present level of fishing mortality is higher than that which gives the maximum yield per recruit and to obtain the maximum yield per recruit $(85.79 \mathrm{~g})$, the fishing mortality coefficient must be reduced from 0.8226 to $0.4(51.37 \%)$.

To determine the most appropriate age at first capture " $\mathrm{T}_{\mathrm{c}}$ " of $R$. kanagurta from the Gulf of Suez, which is related to the estimation of the optimum mesh size, the yield per recruit was estimated by applying different values of $T_{c}(1.5$ and 2 years with the present value 0.97 year). The results (Fig. 3) indicate that with the increasing of $T_{c}$ a higher yield per recruit can be obtained. It is obvious also that if $\mathrm{T}_{\mathrm{c}}$ is 1.5 instead of 0.97 year a maximum yield per recruit of $98.01 \mathrm{~g}$ can be obtained at fishing mortality of 0.6 and if $T_{c}$ is two years a maximum yield per recruit of $107.91 \mathrm{~g}$ can be obtained at fishing mortality of 0.9 which is very close to the present level $(F=0.8226)$. This means that, the present level of $T_{c}$ is not the optimum $T_{c}$ of this fish species in the Gulf of Suez and it must be in the range of two years.

The obtained results are in a good agreement with the finding of Sanders et al. (1984). They concluded that, the stocks exploited by purse-seiners in the Gulf of Suez are fully exploited. They also mentioned that, any additional effort to the purse-seine fishery in the Gulf of Suez will be associated with an annual decrease in the catch.

From the above mentioned results, it is clear that the $R$. kanagurta stock in the Gulf of Suez is in a situation of overexploitation and if the reduction of the fishing mortality coefficient is not possible, the age at first capture must be raised to two years. 


\section{REFERENCES}

Anon, (1985). Report of the Second Working Group Meeting on the Mackerels (Decapterus and Rastrelliger spp.) in the Malacca Strait, 4-9 October 1985, Colombo, Sri Lanka. Bay of Bengal Programme Document. $23 \mathrm{pp}$.

Banerji, S. K. and T. S. Krishnan, (1973). Acceleration of assessment of fish populations and comparative studies of similar taxonomic groups. In: "Proceedings of the symposium on living resources of the seas around India". Spec. Publ., Centr. Mar. Biol. Res. Inst., Cochin, India. 158-175.

Bertalanffy, L. von, (1938). A quantitative theory of organic growth (Inquiries on growth laws. 2). Hum. Biol., 10: 181-213.

Beverton, R. J. H. and S. J. Holt, (1957). On the dynamics of exploited fish population. U. K. Min. Agr. Fish. Food, Ish. Invest., 19: $533 \mathrm{pp}$.

Edwards, R. R. C. and S. Shaher, (1991). The biometrics of marine fishes from the Gulf of Aden. Fishbyte 9 (2): 27-29.

Ford, E., (1933). An account of the herring investigations conducted at Plymouth during the years from 1924 to 1933. J. Mar. Biol. Assoc. U. K., 19: 305-384.

George, K. and S. K. Banerji, (1964). Age and growth studies on the indian mackerel Rastrelliger kanagurta (Cuvier) with special reference to length frequency data collected at Cochin. Indian J. Fish., 11 (2): $621-638$.

Guanco, M. R., (1991). Growth and mortality of indian mackerel, Rastrelliger kanagurta (Scombridae) in the Visayas Sea, Central Philippines. Fishbyte 9(2): 13-15.

Jones, R. and N. P. Van Zalinge, (1981). Estimates of mortality rate and population size for shrimp in Kuwait waters. Kuwait Bull. Mar. Sci., 2: 273-288 . 
Dynamics and management of the indian mackerel 187 Rastrelliger kanagurta (Cuvier, 1816) in the gulf of Suez, Egypt

Lablache, G., G. Augier de Moussac and N. Jivan Shah, (1988). Summary of description of the artisanal fisheries and resources for the Seychelles. In: Sanders, M.J., Sparre, P. and Venema, S. C. (eds.). Proceedings of the workshop on the assessment of the fishery resources in the Southwest Indian Ocean. FAO/UNDP: RAF/79/065/WP/41/88/E. 116-141.

Lee, R. M., (1920). A review of the methods of age and growth determination in fishes by means of scales. Fish. Invest. Min. Agr. Fish., Ser. 2, 4 (2): 1-32.

Luther, G., (1973). Observations on the biology and the fishery of the indian mackerel, Rastrelliger kanagurta (Cuvier, 1816) from Andaman Islands. Indian J. Fish. 20 (2): 425-447.

Pauly, D., (1978). A preliminary compilation of fish length growth parameters. Berichte des Instituts fur Meereskunde an der Christian-Albrechts Universtat Kiel, 55: 200 pp.

Rafail, S. Z., (1972). Studies of Red Sea fisheries by light and purseseine near Al-Ghardaqa. Bull. Inst. Ocean. Fish (Cairo) 2: 2549.

Ricker, W. E., (1975). Computation and interpretation of biological statistics of fish population. Bull. Fish. Res. Bd. Can., 191: 382pp.

Sanders, M. J., S. M. Kedidi and M. R. Hegazy, (1984). Stock assessment for the indian mackerel, Rastrelliger kanagurta caught by purse-seine from the Gulf of Suez and more Southern Red Sea waters. Project for the Development of Fisheries in the areas of the Red Sea and Gulf of Aden, FAO / UNDP RAB / 83/003/03. Cairo. 25 pp.

Seshappa, G., (1958). Occurrence of growth cheeks in the scales of indian mackerel, Rastrelliger kanagurta (Cuvier). Curr. Sci., 27: 262-263. 
Seshappa, G., (1969). The problem of age-determination in the indian mackerel, Rastrelliger kanagurta, by means of scales and otoliths. Indian J. Fish., 16 (1-2): 14-28.

Sudjastani, T., (1973). The species of Rastrelliger in the Java Sea; their taxonomy, morphology and population dynamics. University of British Columbia, Ms thesis. $147 \mathrm{pp}$.

Torres, F. Jr., (1991). Tabular data on marine fishes from Southern Africa, part II : growth parameters. Fishbyte 9 (2): 37-38.

L n, E., (1967). A mathematical model of some aspects of fish growth, respiration and mortality. J. Fish. Res. Bd. Can, 24: 2355-245.

Walford, L. A., (1946). new graphic method of describing the growth of animals: Biol. Bull. Mar. Biol. Lab., Woods Hole, 90 (2): 141-147. 
Table (1). Age composition of Rerstrelliger kammgmter from the Gulf of Suez

\begin{tabular}{|c|c|c|c|c|}
\hline \multirow{2}{*}{ Age (yea) } & \multicolumn{2}{|c|}{ Males } & \multicolumn{2}{c|}{ Females } \\
\cline { 2 - 5 } & Number & $\%$ & Number & 0 \\
\hline I & 19 & 5.54 & 16 & 4.78 \\
II & 197 & 57.43 & 185 & 55.22 \\
III & 106 & 30.90 & 110 & 32.84 \\
IV & 21 & 6.12 & 24 & 7.16 \\
\hline Total & 343 & & 335 & \\
\hline
\end{tabular}

Table (2). Average back-calculated lengths (cm) of Rastrelliger kanagurta (males) from the Gulf of Suez.

\begin{tabular}{|c|c|c|c|c|c|c|}
\hline $\begin{array}{c}\text { Age } \\
\text { group }\end{array}$ & $\begin{array}{c}\text { No of } \\
\text { fish }\end{array}$ & $\begin{array}{c}\text { Empirical } \\
\text { length }\end{array}$ & \multicolumn{3}{|c|}{ Back-calculated lengths at the end of each } \\
& & & 1 & 2 & 3 & 4 \\
\hline & & & & & & \\
I & 19 & 15.50 & $\mathbf{1 4 . 7 9}$ & & & \\
II & 197 & 22.62 & 14.66 & $\mathbf{2 1 . 8 8}$ & & \\
IV & 106 & 26.15 & 14.58 & 21.79 & $\mathbf{2 5 . 6 5}$ & \\
& 21 & 27.61 & 14.55 & 21.68 & 25.57 & $\mathbf{2 7 . 4 5}$ \\
\hline
\end{tabular}

Table (3). Average back-calculated lengths (cm) of Rerwro/higer kanugurta (females) from the Gulf of Suez.

\begin{tabular}{|c|c|c|c|c|c|c|}
\hline \multirow{2}{*}{$\begin{array}{c}\text { Age } \\
\text { group }\end{array}$} & $\begin{array}{c}\text { No. of } \\
\text { fish }\end{array}$ & $\begin{array}{c}\text { Empirical } \\
\text { length }\end{array}$ & \multicolumn{3}{|c|}{ Back-calculated lengths at the end of each } \\
& & & \multicolumn{3}{|c|}{ year of life } \\
\cline { 3 - 6 } & & & 1 & 2 & 3 & 4 \\
III & 16 & 16.35 & 15.59 & & & \\
III & 185 & 2363 & 15.48 & $\mathbf{2 2 . 9 2}$ & & \\
IV & 110 & 27.90 & 15.39 & 22.81 & 27.26 & \\
& 24 & 29.59 & 15.27 & 22.76 & 27.18 & 29.27 \\
\hline
\end{tabular}


Table (4). Calculated weights (g) of Rastrelliger kanagurta (males) from the Gulf of Suez.

\begin{tabular}{|c|c|c|c|c|c|}
\hline \multirow{2}{*}{ Age group } & \multirow{2}{*}{$\begin{array}{c}\text { No. of } \\
\text { fish }\end{array}$} & \multicolumn{3}{|c|}{ Calculated weights at the end of each year of life } \\
\cline { 3 - 6 } & & 1 & 2 & 3 & 4 \\
\hline I & 19 & $\mathbf{3 0 . 2 8}$ & & & \\
II & 197 & 29.44 & $\mathbf{1 0 5 . 9 7}$ & & \\
III & 106 & 28.93 & 104.59 & 176.21 & \\
IV & 21 & 28.74 & 102.91 & 174.46 & $\mathbf{2 1 8 . 9 1}$ \\
& & & & & \\
& & & & & \\
\end{tabular}

Table (5). Calculated weights (g) of Rastrelliger kanagurta (females) from the Gulf of Suez.

\begin{tabular}{|c|c|c|c|c|c|}
\hline \multirow{2}{*}{ Age group } & \multirow{2}{*}{$\begin{array}{c}\text { No. of } \\
\text { fish }\end{array}$} & \multicolumn{3}{|c|}{ Calculated weights at the end of each year of life } \\
\cline { 3 - 6 } & & 1 & 2 & 3 & 4 \\
\hline I & 16 & 36.50 & & & \\
II & 185 & 35.69 & 123.76 & & \\
III & 110 & 35.04 & 121.89 & 214.38 & \\
IV & 24 & 34.18 & 121.05 & 212.40 & $\mathbf{2 6 8 . 5 8}$ \\
& & & & & \\
\hline
\end{tabular}


Table (6) Comparison of growth parameter estimates in Rerstre'lliger komogurfor (sexes combined)

\begin{tabular}{|c|c|c|c|c|}
\hline Locality & $\mathrm{L}_{x}(\mathrm{TL})$ & $\mathrm{K}$ & $t_{0}$ & Author \\
\hline Egypt (Red Sea) & 420 & 0.29 & -0.95 & Rafail, 1972 \\
\hline Egypt (Gulf of Suez) & 40.0 & 0.23 & -.. & Sanders el al. 1984 \\
\hline India & 31.6 & 0.60 & $\ldots$ & Seshappa. 1958 \\
\hline India & 31.3 & 0.64 & -.. & Sekharan ef ol. 1969 \\
\hline India & 39.0 & 0.74 & ... & Luther. 1973 \\
\hline India & 31.6 & 0.60 & -.. & Banerji\&Krishnan, 1973 \\
\hline India & 31.3 & 0.64 & 0.06 & Pauly 1978 \\
\hline Seychelles & 31.7 & 0.64 & $\ldots$ & Lablache of al., 1988 \\
\hline South Africa & 30.3 & 0.72 & -0.198 & Torres, 1991 \\
\hline Philippines & 38.0 & 0.80 & $\cdots$ & Guanco, 1991 \\
\hline Yemen & $32.3 \mathrm{FL}$ & 0.67 & 0.69 & Edward\&Shaher, 1991 \\
\hline Egypt (Gulf of Suez) & & & & The present study, 2001 \\
\hline Males & 29.48 & 0.66 & -0.055 & \\
\hline Females & 32.04 & 0.60 & -0.118 & \\
\hline Sexes combined & 32.15 & 0.57 & -0.053 & \\
\hline
\end{tabular}

Table (7). Total mortality and survival rate estimates of Rastrelliger kanagurta from the Gulf of Suez.

\begin{tabular}{|l|c|c|c|c|}
\hline \multirow{2}{*}{ Method } & \multicolumn{2}{|c|}{ Males } & \multicolumn{2}{c|}{ Females } \\
\cline { 2 - 5 } & $\mathrm{S}$ & $\mathrm{Z}$ & $\mathrm{S}$ & $\mathrm{Z}$ \\
\hline Ricker (1975) & 0.3265 & 1.1193 & 0.3602 & 1.0211 \\
Jones and Van Zalinge (1981) & 0.3254 & 1.1228 & 0.3720 & 0.9889 \\
& & & & \\
\hline Mean & 0.3259 & 1.1211 & 0.3660 & 1.005 \\
\hline
\end{tabular}




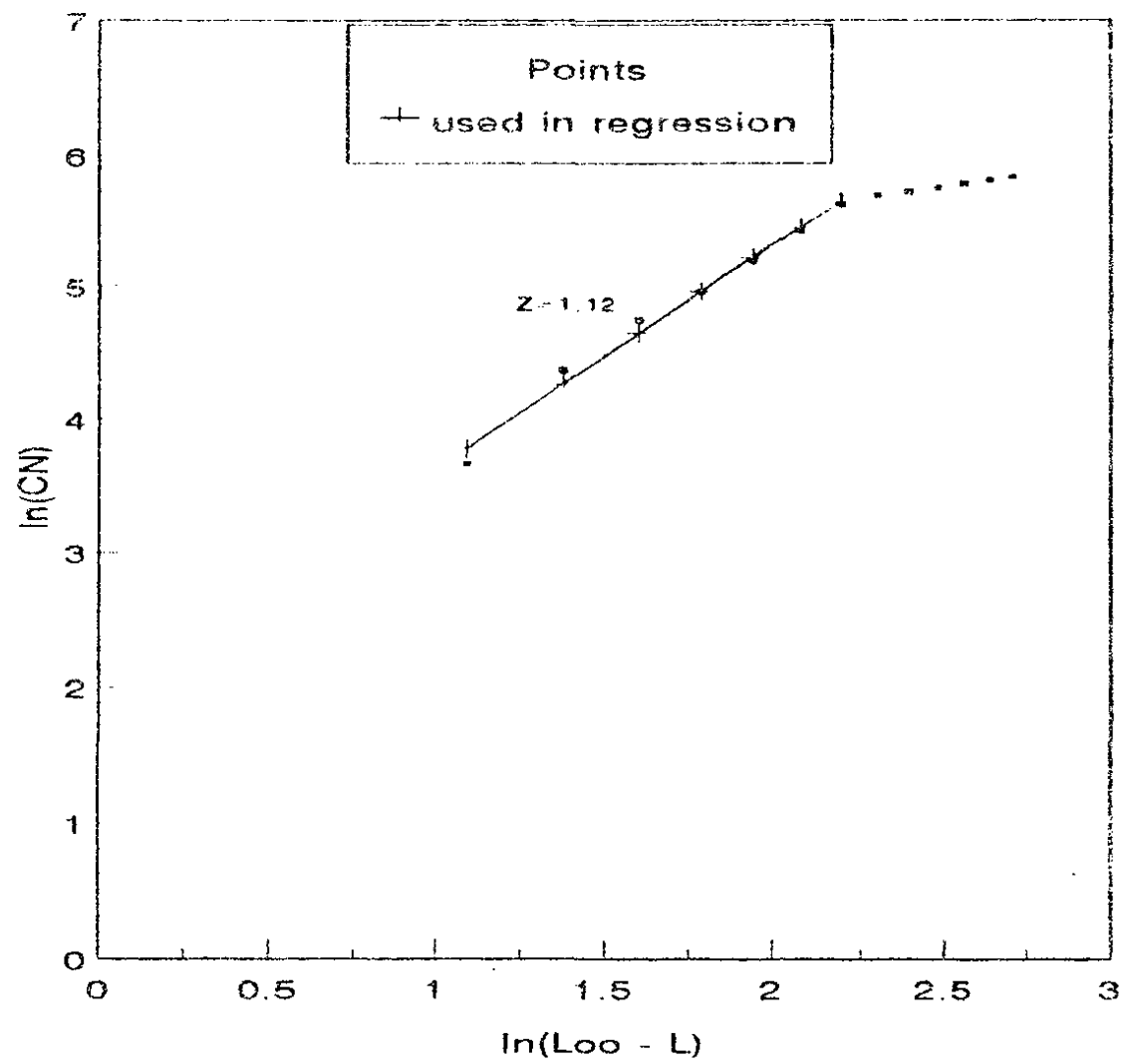

Fig.(1). Estimation of $Z$ of Rastrelliger kanagurta (males)from the Gulf of Suez

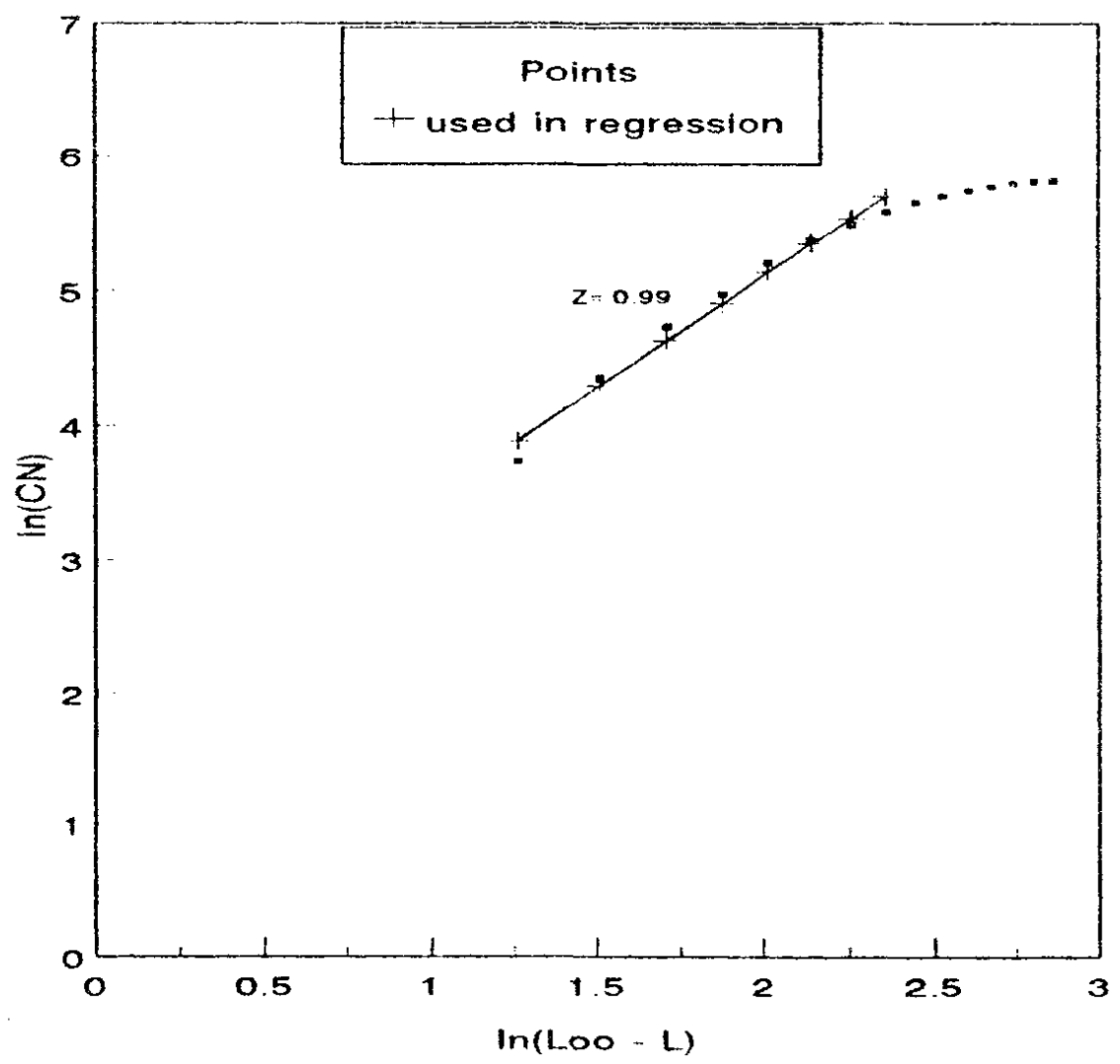

Fig. (2). Estimation of $Z$ of Rastrelliger kanagurta(females)from the Gulf of Suez. 


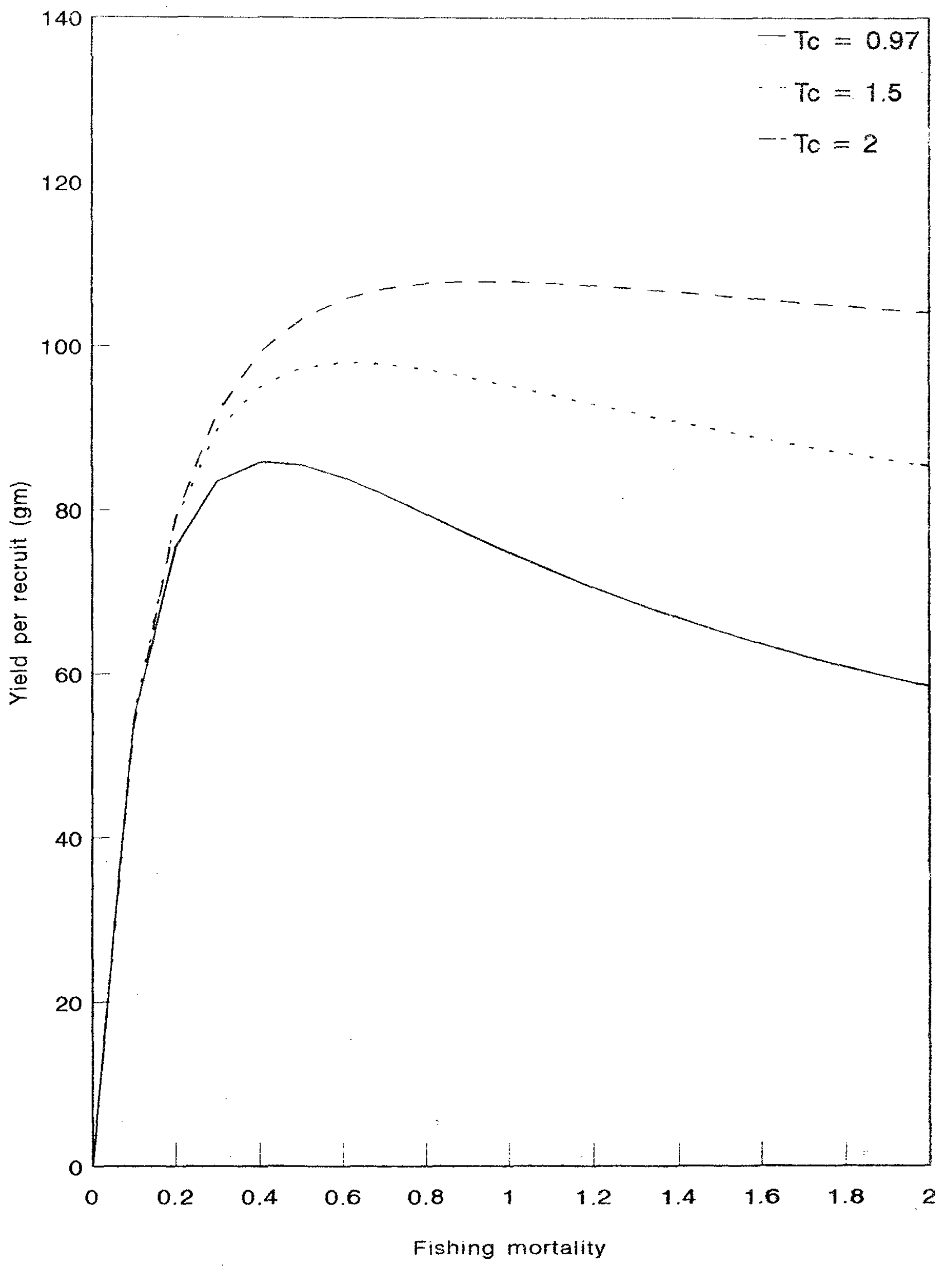

Fig.(3). Yield per recruit of Rastrelliger kanagurta as a function of fishing mortality and age at first capture at the Gulf of Suez. 